\title{
TRAUMATIC PSEUDOANEURYSM OF THE SUPERFICIAL TEMPORAL ARTERY
}

\section{Case report}

\author{
Francisco Sérgio Cavalcante Barros Leal', Carla Ceres Villas Miranda², \\ Antônio Celso Alvarenga Guimarães².
}

\begin{abstract}
A 26 year-old woman suff e red a blunt head injury on the left temporal area and developed an arteriovenous fistula with a pseudoaneurysm on the superficial temporal artery. These fistulas are rare and usually associated with pseudoaneurysms, most commonly in the frontal arterial branch. The aneurysms generally appear late after trauma and present as a pulsatile painfully growing mass in the temporal region, associated with fremitus and bruit. The diagnosis is made by angiography and surgery is a very effective treatment.
\end{abstract}

KEY WORDS: pseudoaneurysm, arteriovenous fistula, head injury, superficial temporal artery.

\section{Pseudoaneurisma traumático da artéria temporal superficial: relato de caso}

RESUMO - Uma mulher de 26 anos desenvolveu uma fístula arteriovenosa associada a pseudoaneurisma da artéria temporal superficial após traumatismo craniano fechado. Tais fístulas são raras e geralmente associadas a pseudoaneurismas da artéria temporal superficial, mais comumente do ramo frontal. As lesões habitualmente surgem tardiamente em relação ao traumatismo causador e se manifestam como uma massa dolorosa pulsátil na região temporal, crescente, associada à frêmito e sopro. O diagnóstico é confirmado através de arteriografia e o tratamento cirúrgico proporciona ótimos resultados.

PALAVRAS-CHAVE: pseudoaneurisma, fístula arteriovenosa, traumatismo craniano, artéria temporal superficial.

The first to recognize an arteriovenous fistula (AVF) as an abnormal communication between an artery and a vein bypassin the capillary circulation was Wlliam Hunter in 1757'. Later in 1740, Thomas Bartholin ${ }^{2}$ reported the first case of temporal artery aneurysm and since then more than 400 cases have been published in the literature ${ }^{3}$. Almeida and Zaclis (1965) ${ }^{4}$ were one of the first Brazilian authors to decribe a case of traumatic pseudoaneunsm on the superficial temporal artery, successfully treated with surgery. Most cases (about $75 \%)^{5}$ a re the result of blunt head injury, but there are cases also related to hair implants ${ }^{6}$, penetrating scalp lesions ${ }^{7}$, external ventricular drainage ${ }^{8}$, use of pintype head holder devices ${ }^{9}$ and at the site of prev ious craniotomy ${ }^{10}$. Arteriovenous malformations associated with pseudoaneurysms of the superficial temporal artery is a rare late complication of head trauma. Of the 262 cases of AVF reported during the Vietnam War, only two $(0.7 \%)$ occurred at the external carotid circulation ${ }^{11}$. Despite the rarity of these lesions, they must be included in the diferential diagnosis of any soft mass in the lateral aspect of the forehead and temporal areas.

Our objective is to report one case of traumatic arteriouvenous malformation associated with a pseudoaneurysm secondary to a blunt head injury (assault) and to discuss its pathophysiology, diagnos is and treatment.

\section{CASE}

A 26-year-old woman with C-type hepatitis was struck on the left fronto-temporal region during an assault and had a five centimeters scalp leson that was treated at the time with wound cleasing and suture. Six weeks later, she was seen ambulatory, and the neurologic examination revealed a soft $25 \times 15 \mathrm{~mm}$ pulsatile frontotemporal mass on the scalp and the patient complained of local pain (Fig 1). A bruit was audible and a fremitus

Neurosurgery Unit of the University Hospital of Taubaté: ${ }^{1} \mathrm{Head}$ of Neurosurgery Unit; ${ }^{2}$ Assistant Neurosurgeon.

Received 15 October 2004, received in final form 29 March 2005. Accepted 13 May 2005.

Dr. Francisco Sérgio C. Barros Leal - Rua Conselheiro Moreira de Barros 159/17 - 12010-080 Taubaté SP - Brasil. E-mail: fcsergio@uol.com.br 


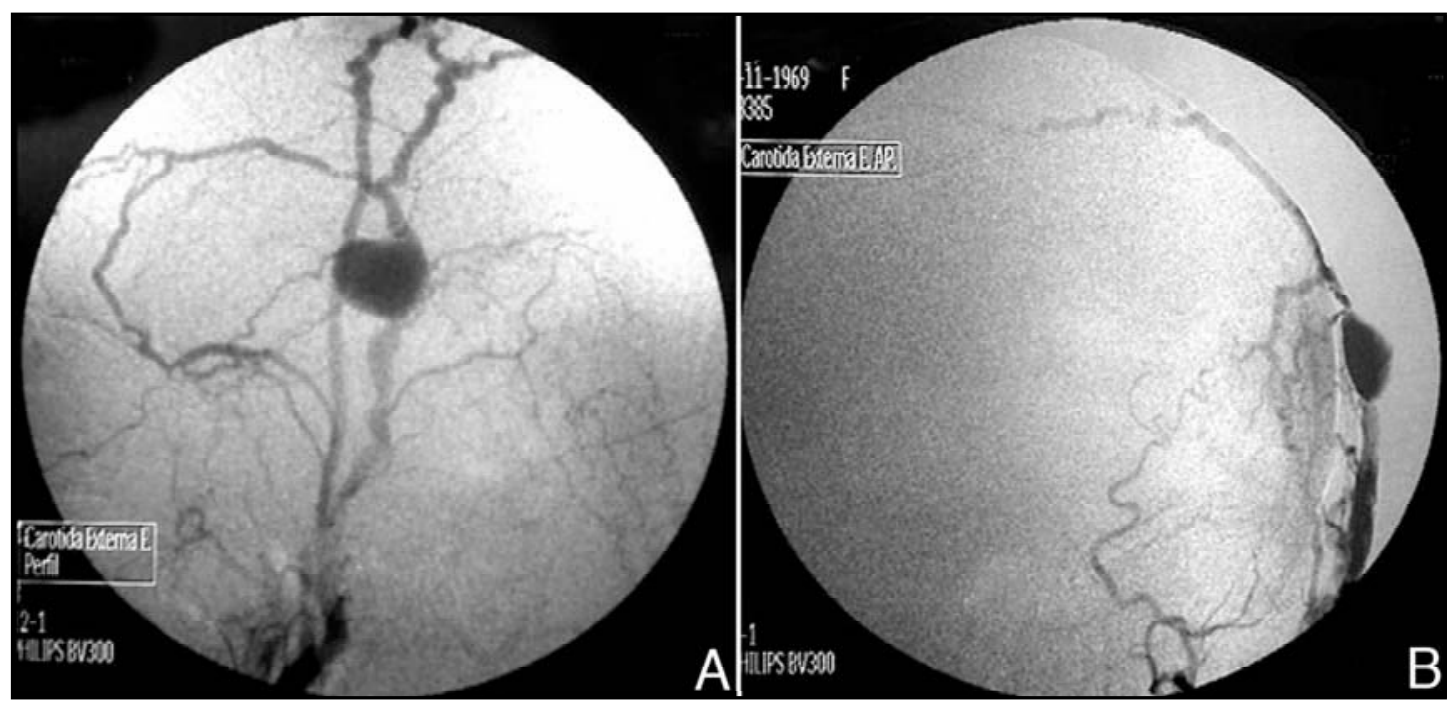

Fig 1. Carotid angiogram with selective left external carotid catheterization (1A and 1B).

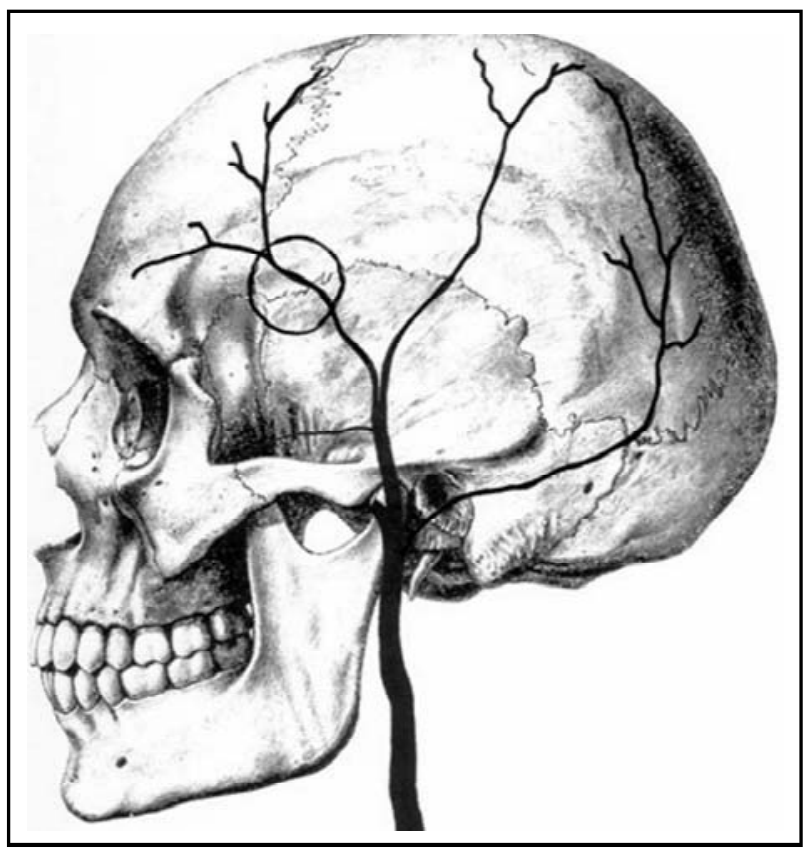

Fig 2. Location of the anterior, middle and posterior branches of the superficial temporal arte ryas it courses over the temporal ridge at the anterior superior orign of the temporalis muscle. In the circled area (superior to the temporalis and lateral to frontal is muscle) the artery is relatively fixed in the galea aponeurotica (muscle gap) and is particularly prone to traumatic lesions and pseudoaneurism formation.

was palpable and both were ceased with digital compression of proximal temporal artery.

She was submitted to carotid angiogram with selective left external carotid catheterization and the diagnosis of AVF with pseudoaneurysm was confirmed. The patient was treated with proximal and distal ligature of the fistula and resecction of the psudoaneurysm under general anestesia which had an uneventful course.

\section{DISCUSSION}

Arteriousvenous fistulas of the scalp are rare vascular lesions usually related to blunt head injury $(75 \%)^{5}$. The usual presentation is that of a painfully pulsatile mass in the frontotemporal between two weeks and four months after the initial trauma, associated with local fremitus and bruit ${ }^{8}$. The superficial temporal art e ry derives from the external carotid artery near the parotid gland and ascends a nterior to the the acoustic meatus towards the frontotemporal region and is separated from the skull only by the temporal muscle. Then, it branches into orbital-zigomatic, middle temporal, anterior auricular, frontal and parietal branches².

These lesions usually occur at the superior temporal line because the anterior arterial branch is u ncushioned by a muscle gap and lies directly on the periosteum (Fig 2). The art e ry is also tethered by the adventitia to the frontalis and temporalis muscles. All these anatomical peculiarities increase the likelihood of lesion in a blunt trauma ${ }^{8}$.

It is believed that the arterial wall is injuried during trauma or there would be a contusion with subsequent wall necrosis ${ }^{13}$. Blood possibly extravasates from the injuried artery with the formation of a hematoma and a pseudocapsule around it. The hematoma capsule would expand and clot would reabsorb resulting in a cavity leading to pseudoaneurysm formation ${ }^{14}$.

The diagnosis is usually suspected by the recent traumatic antecedents and physical examination. Digital compression of the proximal segment on superficial temporal art e ryusually abolishes or de- 
creases the bruit and the fremitus. Differential diagnosis includes simple hematomas, abscess, soft tissue tumors, neuromas and foreign body granulomas. Complementary studies such as Doppler ultrasound and contrast enhanced CT scans may conf i rm or rule out other lesions mimicking a pseudoaneurysm but the deffinitive diagnosis is usually made by angiography ${ }^{9}$.

Treatment is indicated to prevent bleeding, relieve symptoms and for cosmetic purposes. Some authors have reported good results using embolization for the treatment of these lesions ${ }^{15}$ but surgery is the treatment of choice, with ligature of proximal and distal vessels and excision of the pseudoaneunsm. It can be done under general or local anestesia with excelent results ${ }^{13}$.

\section{REFERENCES}

1. Marks MW, Argenta LC, Dingman RO. Traumatic arteriovenous malformation of the external carotid arterial system. Head Neck Surg 1984; 6:1054-1058

2. Han K, Borah GL. Pseudoaneurysm of the anterior superficial temporal artery. Ann Plast Surg 1996;37:50-53.

3. Conner WCH, Rohrich RJ, Pollock RA. Traumatic aneurysms of the face and temple: a patient report and literature review, 1644 to 1988. Ann Plast Surg 1998;41:321-326.

4. Almeida GM, Zaclis J. Pseudo-aneurisma da artéria temporal superficial. Arq Neuropsiquiatr 1965;23:49-51.

5. Bole PV, Munda R, Purdy RT, et al. Traumatic pseudoaneurysm: a review of 32 cases. J Trauma 1976;16:63-70.

6. Davis AJ, Nelson PK. Arteriovenous fistula of the scalp secundary to punch autograft hair transplantation: angioarchitecture, histopathology and endovascular and surgical therapy. Plast Reconstr Surg 1977; 100:242-249.

7. Badejo L, Rockwood P. Traumatic arteriovenous fistula of the scalp: case report. J Neurosurg 1987;66:773-774.

8. Angevine PD, Connolly ES. Pseudoaneurysm of the superficial temporal artery secondary to placement of external ventricular drainage catheters. S Neurol 2002;58:258-260.

9. Fernández-Portales I, Cabezudo JM, Lorenzana L, Gómez L, Porras L, Rodríguez JA. Traumatic aneurysm of the superficial temporal artery as a complication of pin-type head-holder device: case report. Surg Neurol 1999;52:400-403.

10. Morioka T, Nishio S, Hikita T. Traumatic arteriovenous fistulae of the scalp at the area of previous craniotomy. Surg Neurol 1988;30:406-407.

11. Rich NM, Hobson RW II, Collins GJ Jr. Traumatic arteriovenous fistula and false aneurysm: a review of 558 lesion. Surgery 1975;78:817-828.

12. Fox JT, Cordts PR, Gwinn BC. Traumatic aneurysm of the superficial temporal artery: case report. J Tauma 1994;36:362-364.

13. Peik AL, Nichols WK, Curtis J, Silver MD. Aneurysm and pseudoaneurysm of the superficial temporal artery caused by trauma. J Vasc Surg 1988;8:606-610.

14. Manz HJ, Gomes MN. Sports injury as cause of traumatic aneurysm of superficial temporal artery. Arch Pathol Lab Med 1984;198:775-776.

15. Kasdon DL, Altemus LR, Stein BM. Embolization of a traumatic arteriovenous fistula of the scalp with radiopaque gelfoam pledgets: case report and technical note. J Neurosurg 1976;44:753-756. 